\title{
DELEUZE E MASOCH: A FRIEZA DA PORNOLOGIA
}

\author{
Ester Maria Dreher HEUSER \\ Universidade Federal do Rio Grande do Sul \\ esterheu@hotmail.com
}

\begin{abstract}
Resumo: Este ensaio apresenta as aproximações que Deleuze realiza ao excêntrico mundo masoquista no livro Apresentação de Sacher-Masoch por alguns prismas estranhos, se considerarmos a produção de Deleuze em sua totalidade: a importância da teoria fenomenológica da imaginação de Sartre para embasar a tese que atravessa o livro de Deleuze "o masoquismo é uma arte do fantasma"; a relação amistosa que Deleuze estabelece com Freud quando ocupa-se da reflexão filosófica deste no texto Além do princípio de prazer, no qual o filósofo percebe um exercício transcendental do pensamento especulativo do psicanalista: considera o problema dos princípios e encontra a condição de efetividade do princípio do prazer, Tânatos, o instinto de morte. A partir das reformulações deleuzianas dos textos desses pensadores, o ensaio põe em evidência o exercício do método da intuição efetuado por Deleuze ao apresentar a distinção entre as essências masoquista e sádica nas experiências do prazer.
\end{abstract}

Palavras-chave: Pornologia. Masoquismo. Fantasma. Imaginação. Tânatos.

Résume: Cet essai présente les approches que Deleuze réalise à l'excentrique monde masochiste dans le livre Présentation de Sacher-Masoch. Étrange approche, si on considère la production de Deleuze dans sa totalité: l'importance de la théorie phénoménologique de l'imagination de Sartre pour la thèse qui traversé le livre : «le masochisme est l'art du phantasme»; la relation amicale que Deleuze établit avec Freud quand il s'occupe de la réflexion philosofique dans le texte Au-delà du principe de plaisir, discernant une performance transcendante de la pensée spéculative de la psychanalyste, et considérant le problème du principe de plaisir et sa fondement philosophique, Thanatos, l'instinct de mort. À partir des reformulations deleuziennes des textes de ces penseurs, l'essai met en évidence la méthode intuitive utilisé par Deleuze pour faire la distinction entre les essences masochiste et sadique dans l'expérience du plaisir.

Maîtres-mots: Pornologie. Masochisme. Phantasme. Imagination. Thanatos.

Ar rarefeito e sufocante, atmosfera possuída por um carregado perfume impregnado na pesada tapeçaria, ambiente aquecido pelo crepitante fogo da lareira renascentista, lume cujos reflexos enrubescem um pálido rosto de mármore e se espelham no olhar de estátua envolta em uma imensa e sombria peliça. Num jogo de claro-escuro se destacam excitados gestos e sofrimentos impingidos pelo chicote de uma bela, voluptuosa e cruel déspota. Vê-se, em relance, deitado ao chão, como um cão, um escravo, um homem de feições acentuadas sobre as quais é possível ler uma profunda tristeza e abnegada paixão erguer o olhar ardente e fanático de mártir para a imagem de sua Senhora refletida no espelho maciço pendurado na parede, sustentado por uma moldura dourada. Kairós. Gélida imagem congelada em uma paradoxal eternidade efêmera a ser contemplada como se fosse uma estátua, um retrato da escola italiana ou uma fotografia: a pele de zibelina colada ao soberbo corpo que hesita em 
abrir, o kantschuck paralisado suspende a próxima chicotada, o calcanhar que não termina de pisar sobre as costas-tamborete da vítima deitada sobre anúncios de jornais e de papéis assinados em branco compõem um quadro vivo. A vítima, o homem-escravo que observa a imagem fixada dá asas a si mesmo e, à base de cruéis flagelos, passa do corpo à obra de arte, da obra de arte às Idéias. Descorporalização. Ascensão ao ideal. Denegação do mundo carnal, pessoal. Contestação daquilo que é. Neutralização do mundo dado que abre um novo horizonte indeterminado. Produção de um duplo supra-sensual do mundo. Mundo suspenso no fantasma. Fantasma do mundo do qual nascerá um novo homem sem amor sexual. Universo masoquista. Ponto de encontro entre violência e erotismo. Eixo em que a linguagem encontra seu limite próprio. Não-linguagem: união entre aquilo que não fala, ou fala pouco, com aquilo de que não se fala ou de que pouco se fala. Limiar de máxima captação das forças do silencioso fundamento-sem-fundo da vida e da morte: Tânatos.

A esse excêntrico mundo Deleuze se aproxima com sua Apresentação de SacherMasoch, obra em que dirige atenção à questão da perversão na literatura, assim como muitos filósofos franceses do século XX. Entretanto, contrário à tendência dominante que pensou as relações entre a literatura e a perversão com base em Sade, Deleuze pensa-as a partir de Masoch. Tendo no horizonte os procedimentos literários de Sade e de Masoch, além de significativos estudos acerca do sadismo e do masoquismo e a interpretação psicanalítica da síndrome sadomasoquista, Deleuze age como um sintomatologista, um médico da civilização, preconizado em Nietzsche e a filosofia, e antecipa a tese central de seu Crítica e clínica: a literatura é assunto de saúde. Operando com o método da intuição, apresentado no artigo de 1956 A concepção de diferença em Bergson, Deleuze decompõe o misto em duas tendências que diferem por natureza e vai ao encontro das diferenças de natureza entre o sadismo e o masoquismo, chega à diferença interna de cada uma das perversões, demonstra o caráter irredutível do masoquismo, dá-lhe um conceito tão-somente apropriado a ele - cumprindo, assim, o ideal de filosofia de Bergson (Cf. DELEUZE, 1999, p. 98).

Apresentação de Sacher-Masoch é um livro complexo e pode ser abordado por diferentes prismas; nele, temas desenvolvidos em livros anteriores ganham maior força, outros começam a se formular e, também, é o lugar onde alguns temas ganham tratamento exclusivo em toda sua obra. De um lado, o livro pode ser considerado a aproximação mais clássica sobre a questão da literatura em Deleuze, uma vez que, desde seu começo, o problema "Para que serve a literatura?" se impõe (DELEUZE, 1983, p. 17); Sade e Masoch são tratados como exemplos do que Deleuze chama uma "eficácia literária". O filósofo pensa 
os efeitos do romance a partir das funções eróticas da linguagem - os processos de negação em Sade, de denegação e do suspense em Masoch -, os papéis da mulher e do pai nos romances, os elementos narrativos da instituição e do contrato; pensa, ainda, a função clínica da literatura dos dois autores, pois ambos apresentaram aptidão artística e literária para fazer distinções dos mecanismos próprios da essência perversa de uma certa forma da literatura, de expressar a força de dois tipos de sexualidade, de dois tipos de signos ou sintomas distintos, que possibilitaram a criação de dois regimes literários distintos. Por outro lado, Apresentação de Sacher-Masoch pode ser percebido como uma atenção ao problema político em sua relação com a estética: à medida que Deleuze demarca a distinção entre o contrato - como assunto privado, individual, assinado entre o próprio masoquista e a mulher-carrasco - e a instituição - como forma do sadismo, na construção de uma utopia da Razão Pura -, rompe com Kant e toda a linha contratualista, segundo a qual todas as instituições têm seu fundamento sobre contratos de todos com todos. Ainda, por outro lado, o livro pode ser compreendido como o único lugar de toda a produção de Deleuze em que ele pensa a relação pedagógica entre educador e educanda, o perfil de cada um, o tipo de pedagogia, o que deve ser ensinado, o ideal de formação e os meios de atingi-lo (Cf. CORAZZA, 2006, p. 37 e 42). Um diferente e, talvez, o mais surpreendente prisma que esse livro pode ser visto - na medida em que se considera a produção de Deleuze em sua totalidade -, é da relação próxima e amigável que Deleuze estabelece com Freud e a psicanálise. Ainda que critique a mistura entre os mundos masoquista e sádico feita por Freud e a fusão de ambos, que deu origem ao falso conceito de "perversão sadomasoquista", Deleuze mantém-se no registro conceitual psicanalítico. As suas descrições retomam todo o léxico freudiano, como Édipo, pai, mãe, ego, Id, superego, castração, Eros, Tânatos, pulsões e instintos. Mas o ângulo mais misterioso desse olhar sobre o masoquismo é que ele está construído sobre o patrimônio teórico que pertence à tradição da fenomenologia, sem que, porém, Deleuze alguma vez referencie seus autores paradigmáticos, como Husserl, Merleau-Ponty e, sobretudo, Sartre.

\section{Suspensão, a recusa do real}

A grande tese que atravessa o livro - "o masoquismo é uma arte do fantasma" (DELEUZE, 1983, p. 73) - só encontra a sua legitimidade como reformulação da teoria fenomenológica da imaginação, segundo a qual é o processo de suspensão do real que instaura e constitui o mundo das imagens petrificadas que condensam a sensualidade perversa. Mais: a própria afirmação de que a suspensão é conseqüência de um dispositivo 
prévio de denegação do real vem diretamente da leitura de O Imaginário (1940), de Sartre. Em Husserl, a suspensão da crença no objeto visado por uma consciência (ou neutralização do ato posicional) se faz por uma modificação da orientação dóxica da consciência, enquanto crença na existência do objeto fora da consciência, tendo por fundamento a busca de uma radicalidade descritiva dos conteúdos noemáticos da consciência. Isto é, a suspensão se justifica apenas por uma exigência de pureza na apresentação, a si mesma, da consciência nos seus conteúdos puramente significativos. Em Sartre, a passagem da percepção à imaginação, da consciência do real à consciência imaginativa ou imaginária faz-se sempre por um dispositivo de irrealização do objeto perceptivo ou, como dirá Deleuze, por um processo de denegação da realidade do objeto dado. O plano do imaginário só é instaurado por uma recusa violenta do plano do real. É a vontade de escapar à náusea do objeto na sua existência bruta que obriga a consciência a refugiar-se na esfera do imaginário, ou, no caso do masoquista, refugiar-se no fantasma, nas imagens de mármore.

Apesar de nunca se referir a Sartre, no livro Apresentação de Sacher-Masoch Deleuze dá mostras de ter sido marcado pela compreensão existencialista da gênese do fantasma. Quando Sartre pensa a esfera do imaginário enquanto uma das modalidades da consciência, compreende-o como tendo uma posicionalidade que lhe é específica, a imaginação não fica reduzida à imanência da imagem no interior da consciência, como se os objetos imaginados existissem unicamente como conteúdos de atos de imaginação. Pelo contrário, todos os objetos da imaginação são transcendentes à consciência, isto é, existem de modo independente ao ato que os imagina. Todo objeto que a imaginação apreende enquanto objeto imaginado ela o põe, também, como objeto existente. Essa independência ontológica, ou transcendência do objeto, tem como fundamento uma compreensão original da posicionalidade específica do objeto da imaginação e assume, segundo Sartre, quatro formas: 1) pôr o objeto como inexistente; ou 2) pôr o objeto como ausente; ou 3) como existindo em algum lugar, porém, um lugar incerto; ou 4) neutralizar o objeto, quer dizer, não pôr o seu objeto como existente. Contudo, relativo a essa quarta forma de posicionalidade do objeto, em nota, Sartre acrescenta: "esta suspensão da crença permanece um ato posicional” (1940, p. 30). O filósofo ainda qualifica as formas, os atos posicionais: os dois primeiros são atos de negação (o ato 1 é negação da existência; o 2 negação da presença); o terceiro ato é positivo, uma vez que sua existência é afirmada e, o quarto, "corresponde a uma suspensão ou neutralização da tese" (Ibidem), isto é, uma suspensão da posição, da consciência tética do objeto. 
A principal dificuldade da teoria da imaginação de Sartre - dificuldade que, como se verá, Deleuze procurará contornar - consiste em hesitar quanto ao estatuto do quarto modo da posição, aquele que se obtém por suspensão ou neutralização do ato posicional ou ato tético. Por um lado, Sartre diz que ele conduz a uma não-posição. Mas, por outro, Sartre tem o cuidado, como se viu, de, em nota, sublinhar que essa não-posição é ainda um ato posicional. Para esclarecer esse absurdo, ele dá um exemplo em si mesmo mais absurdo ainda:

Existem juízos de percepção que implicam um ato posicional neutralizado. É o que acontece quando vejo um homem que se dirige a mim e acerca do qual eu digo 'é possível que esse homem seja Pierre'. Mas justamente essa suspensão de crença, essa abstenção concerne ao homem que vem. Esse homem, eu duvido que seja Pierre; eu não duvido que seja um homem. Em uma palavra, a minha dúvida implica necessariamente uma posição de existência do tipo: um homem vem em direção a mim. Ao contrário, direi 'eu tenho uma imagem de Pierre' equivale a dizer, não somente 'eu não vejo Pierre', mas ainda 'eu não vejo mesmo nada'. O objeto intencional da consciência imaginante tem isso de particular que ele não existe aí e que é posto como tal, ou ainda, que ele não existe mas que é posto como inexistente, ou que não é posto de todo (Idem, p. 31 e 32).

Pode-se ver que Sartre quer preservar, simultaneamente, duas teses inconciliáveis: a de que a imaginação põe o seu objeto (se bem que como "inexistente") e a de que a imaginação simplesmente não põe objeto algum. O exemplo do juízo perceptivo, na sua arbitrariedade, permite perceber melhor esta dificuldade: ele atribui, em simultâneo, ao juízo de percepção uma posição (a de um homem que vem em direção a mim) e uma não-posição, ou uma inexistência, ou também chamada "dúvida". Em tal atribuição, Sartre confunde a posicionalidade do objeto (um homem qualquer) com a não-posicionalidade da identidade (Pierre) do objeto posicionado (homem). É desta confusão entre sentidos da posicionalidade que decorre a tese de fundo que organiza todo o primeiro capítulo ( $O$ Certo) do livro de Sartre, a saber, que a imaginação põe o seu objeto como um nada. No conceito de "nada" (néant) estão condensadas a posicionalidade e a não-posicionalidade, a crença de que algo existe como correlato de um ato imaginante e a dúvida (ou crença neutralizada, ou ainda suspensão da crença) quanto à existência (possível? irreal?) do objeto imaginado.

Sartre poderia ter resolvido essa inconsistência se tivesse operado uma distinção clara entre dois momentos do ato de imaginação: entre o momento de suspensão ou neutralização da crença na existência atual do objeto e o momento da nova posição, que toma o objeto 
imaginado enquanto existente numa nova condição ontológica (possível, irreal, inexistente, em uma palavra, no nada). É essa distinção que Deleuze, precisamente, vai estabelecer na sua leitura do processo de constituição do fantasma pelo masoquista. Deleuze sublinha o quarto ato do modo da imaginação - a suspensão ou neutralização da posição, que, no entanto, permanece um ato posicional -, distinguindo dois momentos do ato: a denegação e a suspensão que antecedem a produção do fantasma e atribui a eles a própria essência da imaginação ${ }^{1}$. Tal distinção permite a Deleuze determinar a constelação masoquista, fazer de Masoch o inventor, o artista do fantasma por excelência (Cf. DELEUZE, 1983, p. 79).

\section{Perversa constelação masoquista}

Com o talento para desvendar segredos, que lhe é próprio, Deleuze vê nos romances de Sacher-Masoch a presença de uma imaginação que multiplica as denegações do real e percebe nela a essência do processo da arte do suspense masoquista. Sempre por um ato da imaginação, os personagens masoquistas - sob flagelos impingidos pela mulher-carrasco envolta em peles - denegam o real, neutralizam-no, criando, assim, condições para ascender a um horizonte inédito, no qual, pela suspensão do mundo, torna-se possível viver o ideal do fantasma supra-sensual, supra-carnal. Ideal da imaginação pura. Nele, a austera e lasciva mulher, ao ser fixada, é metamorfoseada em obra de arte, nela eternizada, transformada em estátua de pedra, deusa do amor a ser adorada pelo novo homem que dela nasceu e que, agora, destituído de sensações, está mais próximo das fontes da vida e da morte. Elevada ao mais alto grau, sua sensualidade sagrada tornou-se, na imaginação, uma cultura artística reservada apenas para uma mulher ideal, talvez a própria deusa do amor ${ }^{2}$.

\footnotetext{
1 “A denegação em geral não é uma forma de imaginação: ela constitui o fundo da imaginação como tal, que suspende a realidade e encarna o ideal no suspense. Denegar e suspender pertencem à essência da imaginação" (DELEUZE, 1983, p. 135).
}

\footnotetext{
2 Zourabichvili (2007, p. 18 a 20) afirma que o esquema masoquista se deixa decifrar pela estética do romantismo alemão: destaca a importância das estátuas, lembrando de uma antiga escultura de Junon Ludovisi, do qual Goethe encomenda uma cópia para o seu escritório, uma vez que no soberbo rosto da estátua "falam" a graça e a dignidade, referidas, por Schiller, nas Cartas sobre a educação estética do homem. Ao estabelecer relações entre Masoch e Schiller, Zourabichvili lembra a semelhança entre a mulher e a divindade referida por Schiller na Carta 15, que, ao mesmo tempo que atrai irresistivelmente por sua beleza, escapa por ser impenetrável: "A divindade nos traços de mulher reclama a nossa adoração, ainda que a mulher semelhante à divindade inflame o nosso amor. Mas enquanto que, extasiados, nos abandonamos ao seu encanto celeste, a sua suficiência celeste assusta-nos. Toda a sua pessoa se funda em si mesma e na sua permanência; ela é um mundo completamente fechado; como se ela fosse para além do espaço, não se abandona nem resiste; não há aí força em luta com outras forças nem defeito pelo qual o tempo pudesse fazer irrupção. Somos irresistivelmente envolvidos
} 
Deleuze insiste em que, ao denegar o real, Masoch não está negando o mundo, mas suspendendo-o para fixá-lo em um ideal, no fantasma. Isto porque Sacher-Masoch pensa o mundo como fantasma, como ideal, e o seu ato de denegação do mundo é baseado sobre o Ideal da Imaginação, no qual ideal e real são por ele absorvidos (Idem, p. 81). Tal simbiose é o que permite a Deleuze considerar o masoquismo como pura contemplação mística do real, como a produção de um duplo do mundo que é fabulado mediante a acolhida dos excessos e da violência insuportáveis do nosso mundo real. Daí Deleuze pensar o romance masoquista como um tema perverso que se confunde com o próprio movimento da produção ficcional. Uma "ficção do duplo, da reiteração dos fatos, mas como seu arquivo impossível, excessivo" (NABAIS, 2006, p. 79). Ficção que age diretamente sobre os sentidos, que procura espiritualizar os excessos do mundo, assim como a violência deles extraída para devolver-lhe um puro efeito de linguagem. Tal qual um espelho do mundo, na obra de Masoch:

a natureza toda e a história toda devem se refletir no duplo perverso [...] Sob o título geral, O legado de Caim, Masoch tinha concebido uma obra 'total', um ciclo de novelas representando a história natural da humanidade, comportando seis grandes temas: o amor, a propriedade, o dinheiro, o Estado, a guerra e a morte. Cada uma dessas forças devia ser trazida à sua crueldade sensível imediata (DELEUZE, 1983, p. 41).

O espelho, o duplo perverso do mundo, é pensado por Deleuze pela via do fantasma, um ser estranho, objeto impossível que encontra sua realização ideal naquela literatura de caráter ilimitado que ele denomina "pornologia". Muito mais que dar conta da violência erótica por palavras de ordem e demonstrações, por comandos e descrições - aspectos elementares da pornografia -, a pornologia, além de contê-los, ultrapassa-os, fazendo da linguagem um impessoal, porque ela "se propõe a colocar a linguagem em relação com o seu próprio limite, com uma espécie de "não-linguagem"” (Idem, p. 26). Tal relação emerge na medida em que as palavras usadas para expor a exuberância do erotismo, toda a sua violenta sexualidade, agem diretamente sobre os sentidos do leitor e ascendem à esfera das faculdades ${ }^{3}$. No caso de Masoch, o plano impessoal da linguagem é desempenhado pelo Ideal

e atraídos pelo seu encanto, mantidos à distância pela sua suficiência. Encontramo-nos simultaneamente no estado de supremo repouso e no de suprema agitação; e resulta esta maravilhosa emoção pela qual o entendimento não tem conceito nem a língua nome".

${ }^{3}$ Enquanto a pornografia é a literatura do explícito e do rudimentar, a pornologia é a literatura da violência e do erotismo atravessada pela esfera das faculdades: a Idéia da Razão e o Ideal da Imaginação. No caso de Sade, a pornologia passa pelo plano das puras demonstrações das Idéias da Razão, dos problemas ou dos teoremas. No caso de Masoch, a pornologia se constrói por um Ideal impessoal do espírito dialético e, também, por um programa pedagógico de persuasão masoquista que quer transformar a mulher amada em um verdadeiro carrasco 
da imaginação à medida que multiplica as denegações para fazer nascer da frieza um suspense estético. Em outras palavras, a impessoalidade é alcançada quando o suspense devém uma arte do fantasma, composta por fetiches, rituais de sofrimento com verdadeiras suspensões físicas, de poses congeladas da mulher-carrasco, que as fazem parecer com uma estátua, um retrato ou uma fotografia.

\section{0 transcendental e seu fantasma}

No exercício para apreender o masoquismo a partir da sua diferença de natureza, Deleuze fortalece a criação do seu programa filosófico de uma teoria diferencial das faculdades ao produzir uma correlação de essência entre o masoquismo e a faculdade da imaginação. Nesse empreendimento, Deleuze encontra o ponto de gênese da faculdade das imagens no fantasma masoquista, enquanto objeto da imaginação em seu uso transcendente. À altura da história da filosofia depois de Kant, Deleuze faz uma leitura transcendental do masoquismo na medida em que encontra a gênese da faculdade da imaginação, mas também porque desenvolve a questão da perversão no registro de uma pesquisa sobre as condições gerais da experiência - nesse caso, da experiência do prazer - como condições, não de sua possibilidade, mas de sua realidade. Para tal empresa, Deleuze capta forças das especulações filosóficas de Freud.

Em Apresentação de Sacher-Masoch, Deleuze destaca o papel do contrato como condição da denegação, que transpõe a realidade para o fantasma. O masoquista precisa do estabelecimento de um contrato com alguém que adote a função de carrasco, de torturador. Um contrato prévio à relação masoquista que pressupõe, em princípio, o consentimento das partes contratantes, determina, entre elas, um sistema de direitos e deveres recíprocos e, além disso, não pode afetar uma terceira parte e é válido por tempo limitado. Mediante a assinatura do contrato, o qual determina uma relação de Senhora e escravo profundamente desejada pelo masoquista, reina a impressão de que este não passa de um cão, um joguete nas mãos da mulher-carrasco, sua propriedade absoluta. Entretanto, a fria e cruel Senhora é o próprio elemento, a essência mesma do masoquismo realizado, uma vez que ela é a realização do sonho masoquista: gélido, sentimental e cruel. A frieza e a severidade da mulher-carrasco instauram a catástrofe glacial que dá fim à sensualidade, ao amor sexual à medida que são 
denegados. Sob o frio que domina enquanto dura o contrato, perdura a sentimentalidade supra-sensual na figura dessa mulher que, envolvida de gelo, protege-se com peles e é elevada ao caráter fantasista das pinturas das escolas italiana e holandesa (Cf. SACHERMASOCH, 1994, p. 121).

No romance masoquista tudo é denegação, tudo é suspensão, porque tudo é voltado para o fantasma. O romance de Masoch neutraliza o real e suspende o ideal na interioridade pura das imagens petrificadas, isto é, o próprio fantasma, a conseqüência mesma da denegação do real. Real e ideal, portanto, são transferidos para o domínio ficcional das imagens geladas. E a unidade do real com o ideal é obtida no suspense, na pura espera, na petrificação do tempo que define a temporalidade do fantasma. Compreende-se, portanto, que o fetiche - a imagem da mulher em suspensão, transformada em obra de arte - é petrificado e transfigurado em fantasma. O masoquismo, com seu processo de denegação e de suspensão e a decorrente produção do fantasma enquanto mundo Ideal é o efeito fundamental da faculdade da imaginação.

Ainda que Deleuze defina e pense o masoquismo como a arte do fantasma, assim como o exercício da faculdade da imaginação no processo de denegação e de suspensão como essenciais ao romance masoquista, eles não são tomados como exclusivos ao romance masoquista. Há também uma eficácia específica do fantasma, em Sade, que Deleuze considera, assim como um uso sádico da imaginação, como "uma força violenta de projeção, de tipo paranóico, pela qual o fantasma se torna instrumento de mudança essencial e súbita introduzida no mundo objetivo" (DELEUZE, 1983, p. 80). Se Masoch denega o mundo suspendendo-o e fixando-o em um fantasma, Sade nega-o. Deleuze (Idem, p. 29ss), na esteira de Blanchot e Bataille, destaca a presença do negativo em todas as partes da obra de Sade. A imaginação transbordante de Sade - a própria condição de sua sobrevivência ao deserto da Bastilha -, fez avançar os limites do possível para além dos sonhos que jamais alguém foi capaz de sonhar. Sade ultrapassou todos os limites com sua imaginação: utilizou os privilégios que o regime feudal dava a seus senhores e criou uma espécie de homem soberano que, onipotente e impunemente, podia dominar o mundo. Solitária soberania reduzida à negação do valor do outro, de qualquer tipo de ternura, piedade, gratidão e amor; negação das leis, de toda espécie de freio, até mesmo da capacidade de prazer, pois os grandes libertinos são aqueles que neles próprios aniquilaram qualquer capacidade de prazer e de volúpia em nome de um crime de perpétuo efeito, capaz de arrastar para uma corrupção geral, uma perturbação para além da própria vida. Negação, por fim, de sua própria soberania, de si 
mesmo. Autonegação. O gozo pessoal não importa, "só conta o crime, e nem sequer importa que a vítima desse crime seja o próprio, pois apenas importa que o crime atinja o cume do crime" (BATAILLE, 1988, p. 154).

Pela negação absoluta, Sade rompe com a pessoalidade, com a individualidade, e, assim, tenta alcançar a esfera impessoal, a natureza primeira. Deleuze compreende o sadismo como o conflito entre dois níveis: a natureza segunda e a natureza primeira. Donde o negativo da natureza segunda e do Eu, e a negação pura como Idéia da natureza primeira, original que, porém, não pode ser dada nem demonstrada, porque não pertence ao mundo da experiência. Para Deleuze, o grande problema que Sade se põe é o de saber se uma dor pessoal do mundo da experiência pode, por direito, se repetir ao infinito no mundo da natureza primeira, na esfera impessoal. O herói sádico vive, assim, a negação absoluta, total, do mundo: cria uma divisão entre duas naturezas, a primeira, que corresponde às suas exigências, uma natureza da pura negação como Idéia da razão, "acima dos reinos e das leis [...] sem fundo além de qualquer fundo, delírio original, caos primordial feito unicamente de moléculas furiosas e dilacerantes" (DELEUZE, 1983, p. 29); e a natureza segunda - sujeitada às próprias regras e leis - onde o negativo substitui a negação, e surge como o reverso de uma positividade e processo parcial de destruição, pois nela as "destruições são ainda o inverso de criações ou de metamorfoses; a desordem é uma outra ordem, a putrefação da morte é da mesma forma composição da vida" (Ibidem). O sádico vive na troca entre essas duas naturezas e em permanente frustração, porque ele sempre se confronta com o fato de que a natureza, por ele idealizada, não pode ser dada na experiência; assim como porque a natureza real se manifesta menos dolorosa e cruel que a original, objeto de uma louca Idéia, a pura negação é um delírio, mas um “delírio próprio da razão” (Idem, p. 34).

Como conciliar as duas naturezas? Como preencher a distância entre aquilo que se dispõe e aquilo que se pensa sob a onipotência do raciocínio? Para a reprodução infinita da dor entre uma natureza e outra, o libertino cria um sistema que multiplica sem cessar as dores e as vítimas sob a exigência da violência racional, total, impessoal, que não se deixa desviar por nenhum prazer que a conduziria à natureza segunda. A violência sádica é um ato racional, deriva da anulação da natureza pessoal, do Eu sentimental que não conhece a violência além do seu limite de parcialidade sensorial, quer-se matemática, calculada ${ }^{4}$, nas demonstrações

\footnotetext{
${ }^{4}$ Bataille destaca o esforço de Sade para transformar em coisa a imagem que o excita, em trazer a violência autêntica e insuportável à consciência, em fazer falar o objeto do seu delírio, como se coisa fosse, capaz inclusive de ser matematicamente medido: a narração de uma testemunha que diz "mandava que o
} 
para alcançar a repetição da própria "idéia do mal", pensada na natureza primeira. A Idéia da razão pura é, assim, projetada sobre o real como um fantasma. Ao negar o mundo das leis, Sade dá à imaginação um poder de produção de efeitos, um poder de realização, quer dizer, o fantasma sádico é projetado sobre o real, produzindo mais de real: "o fantasma adquire então um poder máximo de agressão, de intervenção e de sistematização no real: a Idéia é projetada com uma rara violência" (Idem, p. 80).

Vê-se, então, em Sade e em Masoch, uma centralidade no papel do fantasma; porém, seu uso é completamente oposto: há uma realização do fantasma no sádico enquanto no masoquista há uma fantasmização, uma neutralização, do real. Idéia da Razão pura em Sade, Ideal da Imaginação pura em Masoch. O fantasma masoquista é o lugar de suspensão do real, que é introjetado, absorvido, no fantasma e investe toda a violência e todo o excesso nas imagens em suspensão, nas cenas paralisadas. Por sua vez, o fantasma sádico intervém no real e amplia, em proporções geométricas, toda a violência pensada pela razão delirante. Pode-se afirmar, então, que o fantasma, como elemento neutralizante ou realizante, joga um papel decisivo no romance perverso, que ele é, por excelência, o instrumento deste gênero de romance que ficciona um duplo do mundo. E, em ambos os casos, a imaginação é seu lugar de nascimento e seu lugar de existência, ao menos no programa filosófico deleuziano dos anos $60^{5}$.

Mas, se há o uso do fantasma e da imaginação tanto nos romances sádicos quanto nos masoquistas, por que Deleuze pensa a relação entre literatura e perversão enfatizando a obra de Sacher-Masoch? Por que o privilégio da experiência masoquista? Afirmou-se, anteriormente que, com Masoch, Deleuze fortalece seu programa filosófico. Afirmação que se explica na medida em que Deleuze encontra o ponto de gênese da faculdade de imaginação no fantasma masoquista, mas também e, sobretudo, porque na singularidade da experiência do prazer, apresentada nos romances de Masoch, Deleuze se depara - seguindo um texto de gênio do criador da psicanálise - com a condição última do próprio prazer, aquela que o

chicoteassem, mas de tempos a tempos, retirava-se para um canto e escrevia num papel o número de chicotadas que acabava de receber'. As suas próprias narrações estão também cheias de medidas: muitas vezes o comprimento dos membros viris é dado em polegadas e em linhas; às vezes um dos participantes diverte-se, durante a orgia, a tirar medidas" (BATAILLE, 1988, p. 171).

\footnotetext{
${ }^{5}$ Nos livros de Deleuze com Félix Guattari, assiste-se a um rompimento com esta associação entre masoquismo, fantasma e imaginação. Em $O$ anti-Édipo (1976), a referência ao masoquismo e ao sadismo desaparece completamente. Deleuze e Guattari não se interessam pelas formas perversas do desejo. Nesse livro o tema da perversão é substituído pelo tema da esquizofrenia.
} 
efetiva, que está para além (ou aquém?) dele. Descoberta freudiana que permitirá a Deleuze pensar o Urmasochismus, um masoquismo original, a perversão mais antiga, anterior ao sadismo, que mais próxima esteve das forças da vida e da morte.

É na reflexão filosófica de Freud, em Além do princípio de prazer (1976), - no qual Deleuze reconhece um exercício transcendental do pensamento especulativo do psicanalista, na medida em que este ousa avançar por espaços desconhecidos e ocupa-se com o problema das condições ou dos princípios, liberando assim novas formas de pensamento e sensibilidade - que Deleuze encontra elementos para pensar a natureza da perversão, mais especificamente, no conceito "instinto de morte". Nesse texto, Freud parte do suposto de que os eventos mentais que se passam com o humano são regulados pelo princípio de prazer, isto é, que, sem exceção, apesar das tensões desagradáveis, dos desvios e desprazeres que a realidade impõe, invariavelmente, evita-se o desprazer - que corresponde a um aumento na quantidade de excitação - em nome de uma produção de prazer - que, por sua vez, corresponde a uma diminuição de excitação. Em outros termos, busca-se sempre a estabilidade, uma constância de baixa excitação, o que define o princípio de prazer (Cf. FREUD, 1976, p. 18). Contudo, levando em conta a experiência geral e alguns casos clínicos de pacientes - que compulsivamente repetem situações indesejadas e emoções penosas, revivendo-as com grande engenhosidade -, não se percebe a dominância do prazer. Um problema que obriga Freud a ter cautela e afirmar que o que existe na mente é "uma forte tendência no sentido do princípio de prazer [...] de maneira que o resultado final talvez nem sempre se mostre em harmonia com a tendência" (Idem, p. 20); tendência que insiste e persiste na busca do prazer, apesar das complicações. Esta cautela leva Freud a considerar a possibilidade da existência de outras tendências nem dependentes nem derivadas do princípio de prazer, "tendências além do princípio de prazer, ou seja, de tendências mais primitivas do que ele e dele independentes" (Idem, p. 29).

É esse, para Deleuze, o momento em que se inicia a reflexão filosófica operada por Freud, pois ele é obrigado a considerar o problema dos princípios, daquilo que governa um domínio. O princípio de prazer é um princípio empírico, ele regula, sem exceção, o domínio da vida psíquica; por isso, o prazer é sistematicamente procurado e a dor evitada. Mas o que faz esse domínio ser submetido a tal princípio? Deve haver uma instância mais alta que submeta a vida psíquica à dominação empírica do prazer, algo que funde o princípio. Qual é a ligação superior que faz do prazer um princípio, que lhe atribui o estatuto de princípio? Eis o problema transcendental que Deleuze sublinha. Eis o que obriga Freud a introduzir um 
princípio transcendental, condição de efetividade, de fundação do princípio de prazer, o que explica a submissão de um domínio a um princípio. No desconhecido terreno daquilo que Freud chamou de metapsicologia seus passos são dados no escuro, as hipóteses são meramente especulativas e as discussões indefinidas, uma vez que nada se sabe "sobre a natureza do processo excitatório que se efetua nos elementos dos sistemas psíquicos" (FREUD, 1976, p. 46), assim como tampouco se sabe sobre a origem da sexualidade. Diante de um problema que se encontra em tão absoluta escuridão, "em que nem mesmo o raio de luz de uma hipótese penetrou" (Idem, p. 78), Freud ultrapassa a biologia - terra de possibilidades ilimitadas - e a psicologia e vê-se obrigado a recorrer a outra região da criação humana a fim de determinar o que faz do prazer um princípio: apela ao mito que remonta à "origem de um instinto, a uma necessidade de restaurar um estado anterior de coisas" (Ibidem [grifo do autor]). Assim, faz de Eros a figura de ligação entre a excitação e sua descarga no prazer: só a ligação da excitação - a ligação energética da excitação, e a ligação biológica das células - torna possível a descarga da excitação, a sua constância (Cf. DELEUZE, 1983, p. 122). Eros, a própria vida tecendo sua rede, unindo células individuais em corpos maiores numa atividade sem fim. Eros, a ligação das complexificações, das sínteses, dos agrupamentos. Eros, idéia que atravessa as várias possibilidades de manifestação da matéria/energia dando sentido a uma variedade de acontecimentos, desde aqueles promovidos pelas forças de atração da matéria inanimada, até aquelas dependentes de sentimentos humanos gregários, tais como o amor, a sexualidade, o carinho, a solidariedade.

\section{Terrível e silencioso princípio transcendental}

Deleuze, porém, faz um pequeno deslocamento na solução de Freud e cria uma resposta para o problema transcendental indo adiante dele, pois compreende que Freud parou no caminho, contrariando, assim, o que é próprio de uma pesquisa transcendental: "Não se pode pará-la quando se quer. Como se poderia determinar um fundamento, sem sermos também precipitados, além ainda, no sem-fundo do qual ele emerge"? (Ibidem). Deleuze retoma o conceito freudiano de "compulsão à repetição" e lhe confere uma nova dimensão, a dimensão transcendental: "essa ligação constitutiva de Eros, nós podemos, devemos determiná-la como "repetição"' (Ibidem). Põe, assim, a repetição em um antes e um depois do prazer, ao mesmo tempo e, em tom enigmático, pergunta: 
Como a repetição representaria um ao mesmo tempo (ao mesmo tempo que a excitação, ao mesmo tempo que a vida) sem representar também o antes, num outro ritmo e numa outra representação (antes que a excitação venha romper a indiferença do inexcitável, antes que a vida venha romper o sono do inanimado)? Como a excitação seria ligada, e seria com isso 'resolvida', se a mesma força também não tendesse a negá-la? (Idem, p. 123 [grifo do autor]).

A solução para o enigma é kantiana. Uma vez que a repetição está, simultaneamente, antes e depois do prazer, a repetição que liga a excitação à sua descarga, que extingue essa ligação e reintroduz o ciclo da excitação, há, assim, uma pura forma da ligação, a própria ligação como a forma mesma da ligação. Em Kant, esta forma é em geral o tempo, o tempo como pura forma, como sentido interno, pois é nele que todas as sínteses e ligações acontecem, é ele, então, a condição última de possibilidade da síntese em geral. Pela idéia de uma compulsão para a repetição, Deleuze demarca a repetição em Além do princípio de prazer como pura forma do tempo:

Deve-se compreender que a repetição, tal como Freud concebe nesses textos de gênio, é nela mesma síntese do tempo, síntese 'transcendental' do tempo. Ela é simultaneamente repetição do antes e do após. Ela constitui no tempo o passado, o presente e mesmo o futuro (Ibidem).

Deleuze percebe que, na medida em que Freud analisa o fenômeno da compulsão para a repetição, ele inverte a relação entre repetição e prazer no interior da própria análise do fenômeno da compulsão para a repetição, e faz dela uma força terrível:

ao invés de viver a repetição como uma conduta para com um prazer obtido ou a obter, ao invés da repetição ser comandada pela idéia de um prazer a reencontrar ou a obter, eis que a repetição se desencadeia, tornou-se independente de qualquer prazer prévio. Foi ela que se tornou idéia, ideal. E foi o prazer que se tornou conduta para com a repetição como terrível força independente (Idem, p. 129).

Mais. Deleuze mostra Freud indo além de Kant, em seu momento de genialidade, uma vez que ele produz uma nova teoria transcendental das sínteses do tempo, com a idéia de negação da ligação, "a repetição-borracha", o dispositivo que apaga a repetição-laço que, como uma nova repetição, constitui o passado e, assim, corta o fluxo contínuo do passado, presente, futuro (Cf. Idem, p. 123). Freud introduziu um outro poder, que está para além do princípio de prazer, outra força além de Eros: Tânatos, o sem fundo. Deleuze, contudo, não 
compreende Eros e Tânatos apenas como uma diferença de natureza entre a união e a destruição, entre a repetição que liga e a repetição que apaga, ele quer manter a dimensão transcendental dos dois conceitos, considerando-os como puras formas da repetição ${ }^{6}$. Formas que não podem ser vividas nem dadas na experiência, pois são a sua condição de efetividade. Na experiência, o que se vive são combinações dos dois, sob a forma de pulsões eróticas e destrutivas.

Cuidadosamente, Deleuze seleciona as palavras e demarca a diferença entre pulsão e instinto, reservando este para designar o conceito freudiano de Todestrieb, o "instinto de morte" e manter o seu estatuto de terrível e silencioso ${ }^{7}$ material a priori, pura forma da repetição que corta, que desfaz a ligação. É essa análise transcendental que permite a Deleuze mostrar o papel fundamental do instinto de morte na compreensão do masoquismo, assim como o papel do masoquismo na compreensão da natureza transcendental dessa instância transcendente e silenciosa. Com a introdução do conceito de "instinto de morte", Freud (1976, p. 76) atribui ao masoquismo um estatuto mais original, reconhece que "pode haver um masoquismo primário". O masoquismo deve ser tomado, então, como mais antigo que o sadismo. Enquanto o sadismo é o instinto de morte orientado não para si mesmo, mas para o exterior, o masoquismo se torna, assim, o fenômeno psíquico mais aproximado desse princípio transcendente e silencioso, que Freud nomeou por Tânatos. Ambos são pensados por Deleuze em relação com Tânatos, mas o sadismo representa a maneira especulativa e analítica de captá-lo, uma vez que é impulsionado pela força do pensamento, da razão, enquanto o masoquismo, movido pela força da imaginação, age por um processo de idealização, mergulha no instinto de morte pela potência do fantasma e representa-o de uma maneira mítica, dialética, imaginária (Cf. DELEUZE, 1983, p. 39 e 125; DELEUZE, 1988, p. 46).

Apesar dessa singular relação com o instinto de morte, sadismo e masoquismo não destronam o princípio de prazer. O que é buscado ainda é o prazer em ambos os casos, entretanto, devido a essa relação com Tânatos, o sofrimento e a dor são indispensáveis para o

\footnotetext{
6 "Eros e Tânatos distinguem-se no seguinte: Eros deve ser repetido, só pode ser vivido na repetição; mas Tânatos (como princípio transcendental) é o que dá a repetição a Eros, o que submete Eros à repetição" (DELEUZE, 1988, p. 47).

${ }^{7}$ Deleuze diferencia ainda a ação de Eros e Tânatos, demarcando que, apesar de ambos não serem dados na experiência, Eros age e se faz ouvir, enquanto que Tânatos, o sem-fundo, embora seja arrastado por Eros até a superfície, mantém-se terrivelmente silencioso (Cf. Deleuze, 1983, p. 124).
} 
encontro com o prazer: "o sádico encontra seu prazer na dor do outro, o masoquista encontra o seu prazer na própria dor” (Idem, p. 127). A dor cumpre, assim, a função de dessexualizar Eros, mortificá-lo, e ressexualizar Tânatos. Eis um movimento paradoxal do princípio de prazer, no qual a frieza e o gelo, expressos por repetidas dores e crueldades inflingidas sobre a carne, são essenciais para a sua efetuação. Eis a própria perversão, que Masoch e Sade, cada um com as especificidades de seus próprios mundos, souberam apresentar como ninguém na literatura perversa, onde o prazer não encontra limites: dessexualização e ressexualização que se manifesta no pensamento e se exprime na força demonstrativa da razão dos personagens sádicos e que, nos visionários heróis masoquistas, manifesta-se na imaginação e se exprime na força mítica das imagens de pedra idealizadas. Irredutibilidade de mundos que Deleuze tornou visível.

\section{Referências}

BATAILlE, Georges. O erotismo. Tradução de João Bénard da Costa. Lisboa: Antígona, 1988.

BERGSON, Henri. O pensamento e o movente: ensaios e conferências. Tradução de Bento Prado Neto. São Paulo: Martins Fontes, 2006.

CORAZZA, Sandra Mara. Artistagens: filosofia da diferença e educação. Belo Horizonte: Autêntica, 2006.

DELEUZE, Gilles. Apresentação de Sacher-Masoch: o frio e o cruel. Tradução de Jorge Bastos. Rio de Janeiro: Taurus, 1983.

Diferença e repetição. Tradução de Luiz Orlandi e Roberto Machado. Rio de Janeiro: Graal, 1988.

A concepção da diferença em Bergson. In. DELEUZE, Gilles. Bergsonismo. Tradução de Luiz B. L. Orlandi. São Paulo: Editora 34, 1999. P. 95-123.

DELEUZE, Gilles; GUATTARI, Félix. O anti-Édipo: capitalismo e esquizofrenia. Tradução de Georges Lamazière. Rio de Janeiro: Imago, 1976.

FREUD, Sigmund. Além do princípio de prazer. In: Edição standard brasileira das obras psicológicas completas de Simund Freud. Rio de Janeiro: Imago, 1976, vol. XVIII. 
NABAIS, Catarina Pombo. L'esthétique en tant que philosophie de la nature: le concept de vie chez Gilles Deleuze. Pour une théorie naturelle de l'expressivité. Regards sur la littérature. Vincennes, Saint-Denis: Université de Paris VIII, 2006. Tese (Doutorado em Filosofia) - École doctorale Pratiques et Théorie du Sens U. F. R. Arts, Philosophie et Esthétique, Vincennes, 2006.

SACHER-MASOCH, Leopold Von. A vénus de kazabaïka. Tradução de Ana Hatherly. Lisboa: Relógio d’Água, 1994.

SARTRE, Jean-Paul. L'imaginaire: psychologie phénoménologique de l'imagination. Paris: Gallimard, 1940.

ZOURABICHVILI, François. Kant com Masoch. Tradução de Eduardo Pellejero. In: Conceito Revista de Filosofia e Ciências do Homem, vol. 2, Dossier Deleuze: Literatura \& Cinema, Lisboa: Eterno Retorno, 2007, p. 5-22. 